\title{
Non-stationary Responses of Tree-Ring Chronologies and Glacier Mass Balance to Climate in the European Alps
}

\author{
Author(s): Giovanni Leonelli, Manuela Pelfini, Rosanne D'Arrigo, Wilfried Haeberli, and Paolo \\ Cherubini \\ Source: Arctic, Antarctic, and Alpine Research, 43(1):56-65. \\ Published By: Institute of Arctic and Alpine Research (INSTAAR), University of Colorado \\ DOI: http://dx.doi.org/10.1657/1938-4246-43.1.56 \\ URL: http://www.bioone.org/doi/full/10.1657/1938-4246-43.1.56
}

BioOne (www.bioone.org) is a nonprofit, online aggregation of core research in the biological, ecological, and environmental sciences. BioOne provides a sustainable online platform for over 170 journals and books published by nonprofit societies, associations, museums, institutions, and presses.

Your use of this PDF, the BioOne Web site, and all posted and associated content indicates your acceptance of BioOne's Terms of Use, available at www.bioone.org/page/terms_of_use.

Usage of BioOne content is strictly limited to personal, educational, and non-commercial use. Commercial inquiries or rights and permissions requests should be directed to the individual publisher as copyright holder. 


\section{Non-stationary Responses of Tree-Ring Chronologies and Glacier Mass Balance to Climate in the European Alps}

\author{
Giovanni Leonelli*\# \\ Manuela Pelfini* \\ Rosanne D’Arrigo $\dagger$ \\ Wilfried Haeberlit and \\ Paolo Cherubini†ई \\ *Department of Earth Sciences, \\ University of Milan, via Mangiagalli 34, \\ Milan, I-20133, Italy \\ $\dagger$ Lamont-Doherty Earth Observatory, \\ Columbia University, 61 Route $9 \mathrm{~W}$ \\ Palisades, New York 10964, U.S.A. \\ \$Department of Geography, University \\ of Zurich, Winterthurerstrasse 190, \\ Zurich, CH-8057, Switzerland \\ $\S W S L$ Swiss Federal Research Institute, \\ Dendro Sciences, Zuercherstrasse 111, \\ Birmensdorf, CH-8903, Switzerland \\ \#Corresponding author: \\ giovanni.leonelli@unimi.it
}

\begin{abstract}
Tree-ring width and glacier mass balance are two highly sensitive climatic proxies which are often used as indicators of biological and geophysical changes in highaltitude ecosystems. Tree-ring data have been widely used to reconstruct past temperatures and also to reconstruct past glacier mass balance. Here we show that tree-ring chronologies from a high-altitude Pinus cembra L. dendroclimatic network and glaciers from the same region in the European Alps have non-stationary responses to air temperature, and have also been responding non-proportionally to temperature extremes in recent decades. Both ring-width chronologies and the mass-balance series of some glaciers from the same region have shown an increasing sensitivity to summer (JJA) temperatures. Our results demonstrate that the sensitivity to climate of tree-ring chronologies and glacier mass balance may change over time and has been increasing in recent decades, posing some limitations to tree-ring-based glacier mass-balance reconstruction. Moreover, we found these reconstructions in the European Alps are more reliable for large rather than for small glaciers, and may not be able to reveal years of extreme ablation that could have occurred in the past.
\end{abstract}

DOI: $10.1657 / 1938-4246-43.1 .56$

\section{Introduction}

The impacts of climate change on physical and biological components of ecosystems are not homogeneous worldwide, and some regions may be more disproportionately impacted than others. Changes in temperature and precipitation regimes (e.g., Jones et al., 1999; Mokhov et al., 2006) and a higher frequency of extreme meteorological events (e.g., Beniston, 2007) have been recorded in many regions worldwide (Intergovernmental Panel on Climate Change, 2007). Changes in the physical and biological components of ecosystems due to climate change are especially evident in those regions where climate factors greatly limit the productivity of local ecosystems (Hughes, 2000; Huber et al., 2005; Barnett et al., 2005). Among the indicators used to understand the ongoing climatic changes, glacier mass balance and tree rings are two of the more sensitive climatic proxies (e.g., Oerlemans, 2001; Hughes, 2002). Glacier net mass balance is the variation in ice mass, expressed in $\mathrm{m}$ w.eq. (water equivalent), and is usually calculated for mid- and high-latitude glaciers as the sum of the winter (accumulation) and summer (ablation) balance at the end of the hydrological year. Net mass balance is influenced by local weather conditions, mostly (summer) temperature and (snow) precipitation. As such it is considered an indicator of climate that reflects largescale atmospheric circulation patterns (Bitz and Battisti, 1999; McCabe et al., 2000; Diolaiuti et al., 2002). In the interior portion of the European Alps, where climatic conditions are moderately continental, mass balance is mostly influenced by the summer temperature regime (Dyurgerov, 2006; Haeberli et al., 2007). How glaciers respond to climatic changes depends, however, on many factors, which are mostly related to the glaciers' size and geometry, but also to their surface characteristics influencing their albedo. For example, debris-covered glaciers are less sensitive to climatic inputs because the rocky layer influences the surface energy exchanges
(Nakawo and Young, 1982; Mihalcea et al., 2006). Changes in mass, and consequently in equilibrium line altitude (ELA) of debrisfree glaciers, on the other hand, are directly driven by climate (Haeberli, 1990; Pelfini and Smiraglia, 1997; Dyurgerov, 2002). As a result, the fluctuation of the glacier terminus, induced by changes in ice mass, have different response times (Oerlemans, 2001), varying from a few years for small, steep mountain glaciers up to several decades or even more than a century for large, flat valley glaciers (Haeberli and Hoelzle, 1995; Hoelzle et al., 2003).

Climate changes can directly impact animals and plants. Their adaptive capacities are known to be species-specific and depend on many factors often directly connected to their physiology (Parmesan, 1996; Hughes, 2000). Trees living in climatically extreme environments record information on the climatic conditions of a region in their annual radial growth (Fritts, 1976; Hughes, 2002). At high altitudes (and high latitudes), trees growing close to the treeline are usually temperature-limited and the derived tree-ring chronologies may be used for proxybased reconstructions of past temperatures (e.g., Briffa et al., 1990; Esper et al., 2002). Long tree-ring chronologies may allow for millennial-long reconstructions of climatic conditions during the growth period of vegetation, providing reliable information on interannual variability and long-term trends.

Both glacier mass balance and tree rings are very sensitive to climate (e.g., Theurillat and Guisan, 2001; Hughes, 2002; Beniston, 2003; Huber et al., 2005; Oerlemans, 2005; Haeberli et al., 2007), and some efforts have been made to reconstruct past glacier mass balance on the basis of dendrochronological data. The main task in such proxy-based reconstructions is the assessment of the past natural variability of a climatic parameter for time periods prior to instrumental measurements. Successful tree-ring-based reconstructions of past glacier mass balance have been produced for the 


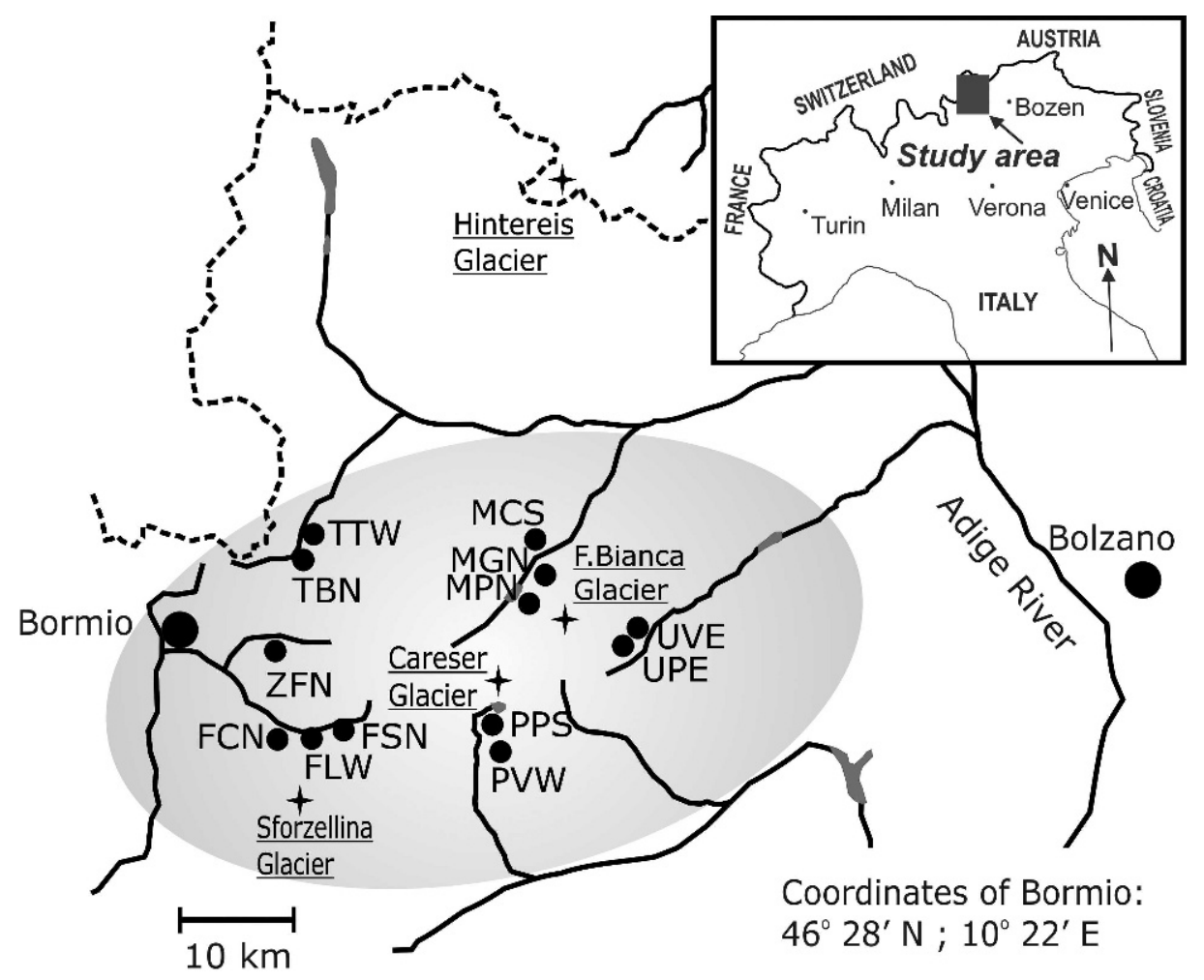

FIGURE 1. Sketch map of the study area. Small filled circles indicate the position of the 13 sampling sites of the dendroclimatic network. Crosses indicate the position of the four glaciers considered. The gray area shows the extent of the Ortles-Cevedale Group.
European Alps and the Western Cordillera of North America. In the European Alps, the best results have been obtained using treering data of Pinus cembra L. (Nicolussi, 1994; Leonelli et al, 2008). Based on a regression model, past mass-balance estimates for the Hintereis Glacier cover about five centuries (Nicolussi and Patzelt, 1996). In the Western Cordillera and the Rocky Mountains, treering based reconstructions have been performed to estimate the past mass balance of four glaciers in a region extending over $\sim 300 \mathrm{~km}$ (Lewis and Smith, 2004), as well as the summer and winter balances of several glaciers (Larocque and Smith, 2005) and of the Peyto Glacier (Watson and Luckman, 2004).

All proxy-based reconstructions are based on the uniformitarian principle, which relies on the stability of relationships between climatic records and proxies. The stability of relationships is established over a common period of record overlap before full reconstructions of past climate are generated. This implies that the sensitivity to climate of both glacier mass balance and tree rings is assumed to be stable over time. However, recent studies, have shown that tree-ring sensitivity to climate may vary over time (Büntgen et al., 2006a; Carrer and Urbinati, 2006; Carrer et al., 2007; Leonelli et al., 2009) and that some divergence between treering chronologies and some climatic records is a global issue (D'Arrigo et al., 2008). This has implications for all tree-ringbased reconstructions. Another problem with long-term reconstructions of a glacier mass balance is that statistical relationships found over the calibration period may be biased since glaciers of the late-20th century are considerably smaller than they were few hundred years earlier, under different climate conditions (e.g., during the Little Ice Age) (Meier at al., 2003). The corresponding effect could indeed amount to a factor of two for the time period since the maximum glacier extent during the Little Ice Age (around 1850 in the European Alps; Nemec et al., 2009).

In this paper, on a yearly resolved base, we test the temporal stability of glacier and tree-ring sensitivity to climate over a common period, with a focus on the potential for tree-ring widths to reconstruct glacier mass balance in the European Alps. These two climatic proxies are compared by analyzing net mass balances from debris-free glaciers of different size, and tree-ring chronologies from a temperature-sensitive high-altitude $P$. cembra network already used in a previous dendroclimatic study (Leonelli et al., 2009). Choosing the same region allowed us to investigate how the same climatic conditions affected these two climatic proxies in an Alpine environment. Particular attention was given to the characterization of the climatic signal recorded in the treering chronologies that show the strongest and weakest correlations with the mass-balance series. This was done to define an approach to select tree-ring chronologies a priori for a mass-balance reconstruction in the region.

\section{Data and Methods}

\section{STUDY AREA}

The aim of our analysis is to test the temporal stability of treering and glacier mass-balance responses to the same climatic input. The tree-ring data came from a high-altitude $P$. cembra tree-ring network composed of 13 chronologies from six valleys of the Ortles-Cevedale Group $\left(46^{\circ} 28^{\prime} \mathrm{N}, 10^{\circ} 34^{\prime} \mathrm{E}\right)$ in the central European Alps (Fig. 1). These were compared with three glacier massbalance series from the same region. The central European Alps are characterized by several mountain groups with many peaks over $3000 \mathrm{~m}$ a.s.l. The Ortles-Cevedale Group, on the Italian side of the Alpine chain, covers an area extending over $30 \mathrm{~km}$ for which a considerable wealth of glaciological, dendrochronological, and meteorological data are available. The climate in the region is moderately continental, with the highest temperatures and precipitation during summer.

\section{MASS-BALANCE DATA}

We considered the net mass-balance series from a valley glacier in the Oetztal Alps, on the Austrian side of the Alpine 
chain (the Hintereis Glacier, $7.7 \mathrm{~km}$ long, with a surface of about $9.5 \mathrm{~km}^{2}$, mean elevation $3020 \mathrm{~m}$ a.s.l., aspect N/NE; National Snow and Ice Data Center, 2007), and the series of a small mountain glacier in the Ortles-Cevedale Group, on the Italian side (the Careser Glacier, with a surface of $4.7 \mathrm{~km}^{2}$, mean elevation $3090 \mathrm{~m}$ a.s.l., aspect S). Additionally, we calculated a regional net mass-balance series for three mountain glaciers from the same mountain group (Fontana Bianca: $0.7 \mathrm{~km}^{2}$ at $3158 \mathrm{~m}$ a.s.l., E; Sforzellina: $0.39 \mathrm{~km}^{2}$ at $2925 \mathrm{~m}$ a.s.1., NW; and Careser: see above for details) after standardizing each series (z-scores) and calculating the mean departures. The three mass-balance series of the Hintereis (HEF; 1953-2003), of the Careser (CAR; 1967-2003), and of the regional group (COMP; 1967-2003) were then standardized, resulting in three mass-balance index (MBI) series (Fig. 2). These were then used in further analyses. The selected series are from debris-free glaciers and are from glaciers at a mean elevation of $3060 \mathrm{~m}$ a.s.1. During the common period 1967-2003, they show a mean mass-balance value of $-0.68 \mathrm{~m}$ w.eq. and a mean autocorrelation of 0.38 (Table 1). All net mass-balance series were obtained from the World Glacier Monitoring Service (W.G.M.S.) (1959-2000 and online values: http://www.geo.unizh. ch/wgms/).

\section{TREE-RING DATA}

The $P$. cembra ring-width chronologies are from 13 highaltitude sites in 6 valleys of the Ortles-Cevedale Group. We prepared the dendrochronological data by removing the nonclimatic growth-trend due to tree age or stand disturbances in the tree-ring chronologies (Fritts, 1976), preserving low-frequency variability in the resulting chronologies. For each site, raw measurements were transformed into ring-width index series by dividing each value by the one predicted by the regional curve (RC; Esper et al., 2003). The RC was calculated by aligning all the measurement series according to their cambial age and smoothing the mean values with a cubic spline $10 \%$ of the series length (Büntgen et al., 2006b). A biweight robust mean was applied to all the series, finally resulting in the site chronologies. A mean chronology was also prepared by averaging all 13 site chronologies. Moreover, six subsets of the tree-ring chronologies were created by averaging the four chronologies with the strongest (Schr_HEF, Schr_CAR, and Schr_COMP) or the weakest (Wchr_HEF, Wchr_CAR and Wchr_COMP) absolute correlation values with the three different MBI series (Fig. 2 and Table 2). The tree-ring chronologies are from sites with mean elevations ranging from 2100 to $2250 \mathrm{~m}$ (mean 2190), mainly from $\mathrm{N}$-facing slopes. The mean ring widths range from 0.7 to $1.6 \mathrm{~mm}$ (mean 1.2) and the series have a first-order autocorrelation ranging from 0.7 to 0.9 (mean 0.8 ) (Table 1).

\section{METEOROLOGICAL DATA}

Meteorological gridded data (monthly and seasonal anomalies) from 1865 to 2003 for the region comprising the study area were taken from the HISTALP database (Auer et al., 2007), grid point $46^{\circ} \mathrm{N}, 10^{\circ} \mathrm{E}$. Anomalies refer to the 20 th century means (1901-2000) and were derived only from homogenized data, both for the seasonal and monthly temperature series (high-altitude record, $>1400 \mathrm{~m}$ a.s.1.). July and summer temperatures over the region show an increasing trend over the last century and recent decades (Fig. 2), whereas precipitation does not show any particular trend for either monthly and seasonal totals (not shown).
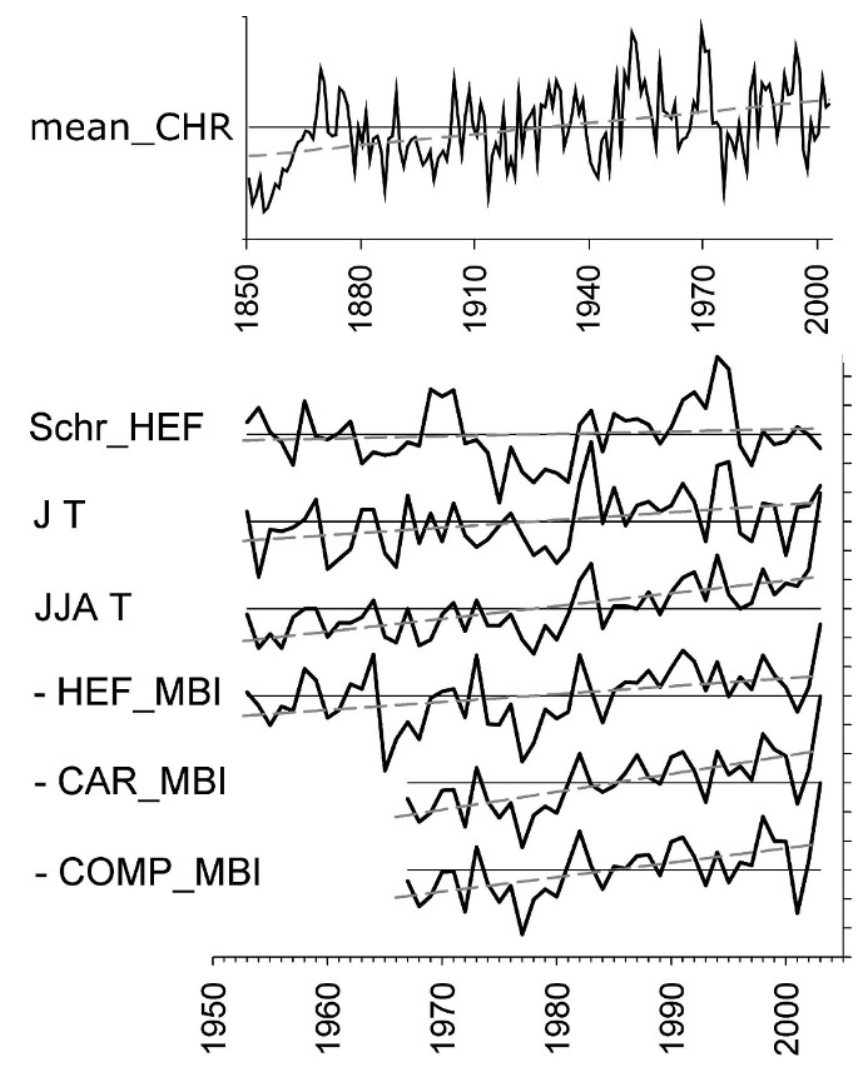

FIGURE 2. Z-scores of the most important time series used in this study computed over different time periods: mean tree-ring chronology (mean_CHR; 1850-2003); mean of the four tree-ring chronologies showing the strongest absolute correlation values with the Hintereis series (Schr_HEF; 1953-2003); July temperature (J T; 1953-2003) and summer temperature anomalies (JJA T; 19532003), HISTALP series (Auer et al., 2007); inverted standardized mass-balance series of Hintereis, Careser and the Composed series (HEF_MBI; CAR_MBI; COMP_MBI; computed over the longest periods available).

\section{CLIMATIC ANALYSIS}

The selected glacier and tree-ring series were compared with the monthly and seasonal climatic variables during the same periods using classical and moving correlation analyses. Monthly and seasonal climatic analyses were performed on the Schr and Wchr series to check the sensitivity of the tree-ring growth to climate in the two groups of chronologies. Tree-ring chronologies were analyzed for the period 1968-2003, selecting the temperature and precipitation variables from October of the year prior to growth to September of the year of growth, as these generally represent the hydrological year (Leonelli et al., 2008) and from spring (MAM-1) of the year prior to growth up to autumn (SON) of the year of growth. The months prior to growth are commonly selected in dendroclimatic analysis because annual growth is influenced by important biological lags (e.g., needle retention, bud formation, carbohydrate storage) which are the reason for autocorrelation in the tree-ring series (Fritts, 1976). The same method was used to evaluate the mass-balance series relationships to climate.

For the moving correlation analysis, we analyzed 30-year periods progressively shifted by one year from 1953 to 1982 (1967 to 1993 for CAR and COMP series) up to 1974-2003. We calculated the bootstrapped Pearson's correlation coefficients (1000 iterations) between both the dendrochronological and the 
TABLE 1

The main characteristics of the site and the dendrochronological/ glaciological series. $A R 1=$ first order autocorrelation referred to the regional curve (RC) and mass-balance index (MBI) series. The first letter of the site chronology codes corresponds to the first letter of the valley names $(\mathrm{F}=$ Forni; $\mathrm{M}=$ Martello; $\mathrm{P}=$ Peio; $\mathrm{T}=$ Trafoi; $\mathrm{U}$ $=$ Ultimo; $\mathrm{Z}=$ Zebrù) and the middle letter identifies the site in the valley. The last letter corresponds to the site slope aspect. HEF $=$ Hintereis MBI; CAR = Careser MBI; COMP = Composed MBI.

\begin{tabular}{|c|c|c|c|c|c|}
\hline & $\begin{array}{c}\text { Mean } \\
\text { Elevation } \\
\text { (m a.s.1.) }\end{array}$ & Aspect & $\begin{array}{c}\text { Mean } \\
\text { Segment } \\
\text { Length (yr) }\end{array}$ & $\begin{array}{c}\text { Mean } \\
\text { Tree-Ring } \\
\text { Width }(\mathrm{mm})\end{array}$ & AR 1 \\
\hline FCN & 2250 & $\mathrm{~N}$ & 217 & 1.106 & 0.644 \\
\hline FLW & 2200 & W & 210 & 1.157 & 0.784 \\
\hline FSN & 2170 & $\mathrm{~N}$ & 232 & 0.949 & 0.789 \\
\hline MCS & 2230 & $\mathrm{~S}$ & 265 & 0.713 & 0.769 \\
\hline MGN & 2190 & $\mathrm{~N}$ & 133 & 1.612 & 0.892 \\
\hline MPN & 2110 & $\mathrm{~N}$ & 166 & 1.314 & 0.818 \\
\hline PPS & 2230 & $\mathrm{~S}$ & 231 & 0.904 & 0.847 \\
\hline PVW & 2250 & W & 201 & 1.318 & 0.826 \\
\hline TBN & 2100 & $\mathrm{~N}$ & 203 & 1.070 & 0.684 \\
\hline TTW & 2150 & W & 245 & 0.950 & 0.754 \\
\hline UPE & 2150 & $\mathrm{E}$ & 175 & 1.434 & 0.541 \\
\hline UVE & 2250 & E & 157 & 1.410 & 0.875 \\
\hline \multirow[t]{2}{*}{ ZFN } & 2180 & $\mathrm{~N}$ & 194 & 1.230 & 0.690 \\
\hline & $\begin{array}{c}\text { Mean } \\
\text { Elevation } \\
\text { (m a.s.1.) }\end{array}$ & Aspect & $\begin{array}{c}\text { Series } \\
\text { Length } \\
(\mathrm{yr})\end{array}$ & $\begin{array}{c}\text { Mean Mass } \\
\text { Balance Value } \\
\text { (m w.eq.) }\end{array}$ & AR 1 \\
\hline HEF & 3020 & $\mathrm{E} / \mathrm{NE}$ & 51 & -0.475 & 0.314 \\
\hline HEF_1967 & “ & “ & 37 & -0.534 & 0.400 \\
\hline CAR & 3090 & $\mathrm{~S} / \mathrm{S}$ & 37 & -0.849 & 0.437 \\
\hline COMP & 3060 & - & 37 & -0.668 & 0.291 \\
\hline
\end{tabular}

glaciological series, and summer (JJA) temperatures, spring (MAM) and summer (JJA) precipitation. Seasonal precipitation variables were chosen according to the statistically significant results obtained from the monthly analysis of mass balance and of the chronologies, respectively. Correlation coefficients calculated over 30-year periods may be highly variable. However, a period of 30 years is a standard commonly used in climatology to assess climate normals and it also adapts well to the selected massbalance series lengths. The significance of the correlation coefficients for the overlapping intervals was assessed using the Bonferroni correction method, which adjusts confidence levels when multiple statistical tests are evaluated simultaneously (Snedecor and Cochran, 1989). Statistical comparisons between tree rings and glacier mass balance were performed using only the three Schr chronologies (Schr_HEF,_CAR, and _COMP).

A linear regression of the MBI series on the Schr series was also performed for the longest time period available and on the common period 1967-2003. To investigate the influence of nonproportional impacts arising from extreme temperature, a second linear regression was calculated after excluding the year 2003, which is an outlier in the temperature record due to the an extremely hot summer in Europe.

\section{Results}

The correlations between all the dendrochronological and glaciological series, calculated for the common period 1967-2003 showed that the glacier series were most strongly correlated to one another $(r \geq 0.90, p<0.001$; Table 3$)$. The mean value of the correlation coefficients calculated in all the comparisons between
TABLE 2

Constituents of the Schr and Wchr chronologies. The two groups of chronologies, Schr and Wchr, are defined as subsets of the site chronologies presenting the four strongest (Schr) and the four weakest (Wchr) correlation values versus the three MBI considered. Only the chronologies of the Schr group were used to compare the dendrochronological series with the MBI series. The groupings for the CAR and the COMP MBI series are identical.

\begin{tabular}{lllc}
\hline \hline \multirow{3}{*}{ Schr } & HEF & CAR & COMP \\
& FLW & FLW & FLW \\
& FSN & FSN & FSN \\
& TTW & PPS & PPS \\
\multirow{4}{*}{ Wchr } & ZFN & PVW & PVW \\
& FCN & FCN & FCN \\
& MCS & MCS & MCS \\
& PVW & UPE & UPE \\
& UPE & UVE & UVE \\
\hline
\end{tabular}

the pairs of tree-ring chronologies is 0.56 . Many of the coefficients are significant at the $p<0.001$ level (Table 3). The FCN chronology correlated least with the other chronologies, with up to three non-significant correlations.

The climatic analysis on the Schr and Wchr series, performed for the period 1968-2003, revealed that the chronologies correlating better with the MBI series (the Schr) are those containing the strongest $\mathbf{J}$ and JJA temperatures signals (Figs. 3a and $3 \mathrm{~b}$, respectively). These chronologies also showed that JJA-1 temperature had a positive influence on tree-growth and that March precipitation (springtime snow) had a negative influence on tree-ring width. The Wchr chronologies had, in contrast, a negative correlation with the previous winter (D-1JF) and February temperatures. In all the chronologies the previous autumn (SON-1) temperature had a positive influence on treering width and summer precipitation (JJA P) a negative influence.

The three glaciological series correlated with the climatic inputs in an almost opposite way to the tree-ring chronologies (especially with respect to the seasonal variables). The summer (JJA) temperature had the strongest influence on net mass balance and all summer months were significantly and negatively correlated (Figs. 3c and 3d). Positive correlations were found with previous Winter (D-1JF), Spring (MAM), and summer (JJA) precipitation.

The sensitivity of the Pinus cembra mean chronology to JJA temperatures varied over time, and the correlation coefficient values calculated for 30-year periods tend to increase (Fig. 4a). The values up to $r=0.64$ for the 1973-2002 period are evidence of a recent trend towards a greater sensitivity. A trend towards a higher sensitivity to JJA precipitation was also found for the mean chronology in the recent period (Fig. 4a).

In general, the Hintereis series (HEF) showed stronger correlation values with summer temperatures than the massbalance series of the smaller glaciers. However, the correlations were always significant $(p<0.001)$ for all the series and in all the intervals considered (Fig. 4b). Correlation coefficients reveal a generally increasing sensitivity of the glaciers to summer temperatures (this is especially evident for the Hintereis). A marked trend of a higher influence of MAM precipitation on glacier mass balance is especially evident for the Hintereis Glacier since the period 1967-1996 up to the latest 30-year periods analyzed (Fig. 4b).

Correlations between the three MBI series and the three Schr tree-ring chronologies (Schr-HEF, -CAR, and -COMP) in general 
TABLE 3

Correlation coefficients calculated over the common period 1967-2003 between the 13 RC site chronologies and between the three MBI series selected for this study. Significant values at the $p<0.001$ level are written in bold; non-significant values $(p>0.05)$ are written in italics. Abbreviations as in Table 1.

\begin{tabular}{|c|c|c|c|c|c|c|c|c|c|c|c|c|}
\hline & FCN & & & & & & & & & & HEF & \\
\hline FCN & 1.00 & FLW & & & & & & & & HEF & 1.00 & Car \\
\hline FLW & 0.60 & 1.00 & FSN & & & & & & & Car & 0.90 & 1.00 \\
\hline FSN & 0.16 & 0.70 & 1.00 & MCS & & & & & & Comp & 0.90 & 0.96 \\
\hline MCS & 0.49 & 0.68 & 0.39 & 1.00 & MGN & & & & & & & \\
\hline MGN & 0.61 & 0.73 & 0.31 & 0.68 & 1.00 & MPN & & & & & & \\
\hline MPN & 0.64 & 0.71 & 0.21 & 0.66 & 0.94 & 1.00 & PPS & & & & & \\
\hline PPS & 0.01 & 0.44 & 0.47 & 0.63 & 0.41 & 0.37 & 1.00 & PVW & & & & \\
\hline PVW & 0.18 & 0.65 & 0.59 & 0.70 & 0.48 & 0.44 & 0.84 & 1.00 & TBN & & & \\
\hline TBN & 0.16 & 0.70 & 0.72 & 0.69 & 0.47 & 0.45 & 0.73 & 0.74 & 1.00 & TTW & & \\
\hline TTW & 0.41 & 0.74 & 0.59 & 0.77 & 0.60 & 0.60 & 0.78 & 0.74 & 0.81 & 1.00 & UPE & \\
\hline UPE & 0.79 & 0.68 & 0.22 & 0.81 & 0.72 & 0.74 & 0.31 & 0.47 & 0.43 & 0.58 & 1.00 & UVE \\
\hline UVE & 0.88 & 0.62 & 0.13 & 0.68 & 0.62 & 0.69 & 0.13 & 0.35 & 0.26 & 0.46 & 0.91 & 1.00 \\
\hline ZFN & 0.68 & 0.76 & 0.65 & 0.56 & 0.51 & 0.52 & 0.31 & 0.41 & 0.55 & 0.68 & 0.63 & 0.65 \\
\hline
\end{tabular}

reveal a convergence between these two climatic proxies in recent decades, especially since the period 1965-1994 (Fig. 5). The correlations were generally stronger for the large glacier and always significant, except in the period 1968-1997 for the COMP series of mass balance. Since the period 1970-1999, the Careser series has also shown stronger correlations with tree-ring data, nearly reaching the Hintereis values.

A linear regression of the MBI series HEF and CAR on the respective Schr series was performed for the period 1953-2003 and for the common period 1967-2003 (Fig. 6). Regressions were calculated using complete series and series without the year 2003, which is an outlier in the mass-balance series. The regression of MBI series on the tree-ring chronologies consistently showed negative slopes. Tree-ring chronologies could explain higher percentages of variations in the mass balance of the Hintereis Glacier (21\%, and 26\% in the 1967-2003 period) than of those of the Careser Glacier (16\%). After removing year 2003 from the analysis, higher proportions of the mass-balance variations were explained by the tree-ring chronologies. Tree-ring chronologies explained up to $25 \%$ (33\% in the 1967-2003 period) of the variations in the Hintereis series and up to $20 \%$ in the Careser series. The COMP series always showed the lowest values for the coefficient of determination and non-significant regressions (data not shown).

\section{Discussion}

Recent research in the European Alps indicates that tree-ring sensitivity to climate may change over time. Büntgen et al. (2006a) found a variation in sensitivity to climate in a high-altitude Picea abies tree-ring network, Carrer and Urbinati (2006) in a Larix decidua network, and Carrer et al. (2007) in a P. cembra network. The climate sensitivity of the $P$. cembra dendroclimatic network used in this study also appeared to change over time, depending partly on site slope aspect (Leonelli et al., 2009). Chronologies from $\mathrm{N}$-facing sites showed almost stable relationships with JJA temperature over time, whereas chronologies from $\mathrm{S}$ - and $\mathrm{W}$-facing sites showed a dramatic decrease in sensitivity. In the present study the moving correlation analysis revealed an increasing sensitivity of the mean chronology to JJA temperatures (Fig. 4a). However, the analysis was performed for 30 -year periods, which is half the length of the time period used in Leonelli et al. (2009). Using this time scale may induce higher variability in the correlation coefficients than using longer time periods.
The synchronicity and the similar patterns of the massbalance series reflect a regional climatic signal. In general, glaciers within the same region typically present similar patterns in the icemass variation, and the similarity of glaciological series tends to decrease with an increasing distance between glaciers (Cogley and Adams, 1998; Diolaiuti et al., 2002; Letréguilly and Reynaud, 1990). However, the Hintereis mass-balance series generally showed a stronger correlation with the JJA temperature, revealing a different response to climate from those of the other two series from smaller glaciers (Fig. 3d).

Our findings also indicate that the same climatic conditions over a region may result in non-proportional variations in a glacier mass balance and in tree-ring growth, with the years presenting extreme variations in the mass balance being the least likely to be correctly estimated by these relationships. A clear example of this is summer 2003, when a heat wave occurred over Europe and the Alps. Glaciers then underwent extreme melting, whereas the tree-ring width increment at high altitudes was not particularly enhanced (Fig. 2). Glaciers in the Alps seem to be increasingly showing signs of downwasting and collapse due to rapid warming rather than "retreat" (Haeberli et al., 2007). The influence of local factors like topographic features and the increasing areas covered by rock outcrops in the glacier bodies largely depends on glacier size: under similar climatic conditions, glacier fragmentation and melting rates are especially high for small and thin glaciers (Paul et al., 2004). This could also explain the weaker correlations of the mass balance of small glaciers with summer temperature (Figs. 3c and 3d). Smaller glaciers, like the ones selected for this study, are the most likely to disappear first from the alpine landscape. In fact, some of them, including the Careser Glacier, are already close to full disintegration (Paul et al., 2004; Carturan and Seppi, 2007). Moreover, positive feedbacks accelerate glacier melt, such as a decrease in albedo due to firn area loss and dust/soot deposition on ice/firn surfaces (Oerlemans et al., 2009; Paul et al., 2005).

A convergence between glacier mass change and temperature records has also been reported on the global scale (Dyurgerov, 2006). The mass balance of glaciers may be considered an integrator of large-scale atmospheric circulation and surface climatic factors, and may thus be interpreted as the first indicator of an undelayed climate signal (Solomina et al., 2008). The sensitivity of a glacier's mass balance has a regional/climatic component (continentality, mass-balance gradient) as well as an individual/topographic component (hypsography: distribution of 

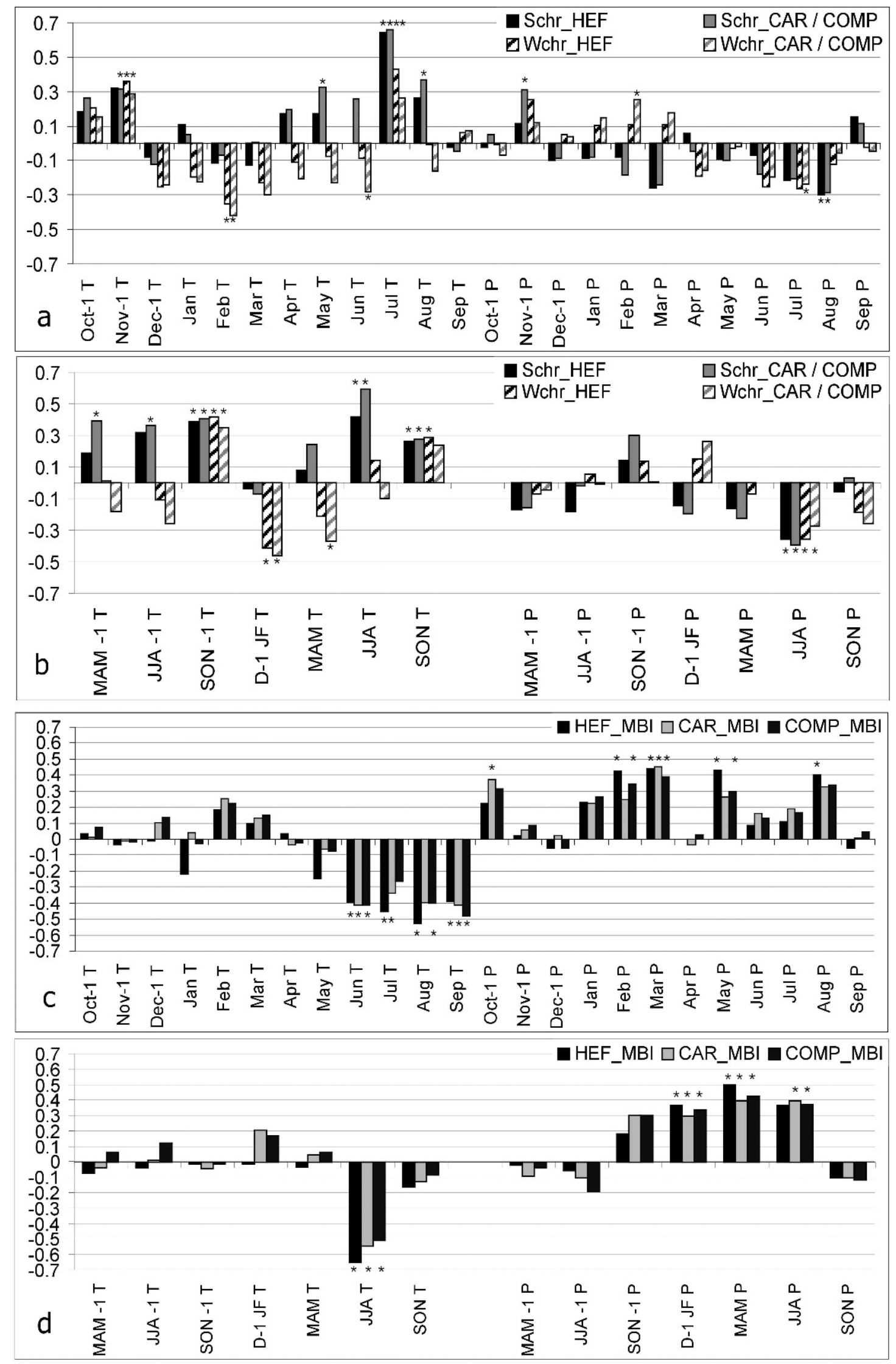

FIGURE 3. Bootstrapped correlation function coefficients calculated over the period 1968-2003 between monthly and seasonal climate variables and the Schr and the Wchr series $(\mathrm{a}, \mathrm{b})$. The climatic analysis was performed from October 1 of the year prior to growth to September of the year of growth (a) and from spring (MAM-1) of the year prior to growth to autumn (SON) of the year of growth (b). The same analysis over the same time period was performed on the Hintereis (HEF_MBI), the Careser (CAR_MBI), and the Composed series (COMP_MBI) (c, d). Correlation significance was assessed by means of the 95th percentile range: asterisks represent significant values at the $p<0.05$ level. $T=$ temperature; $\mathbf{P}=$ precipitation. 

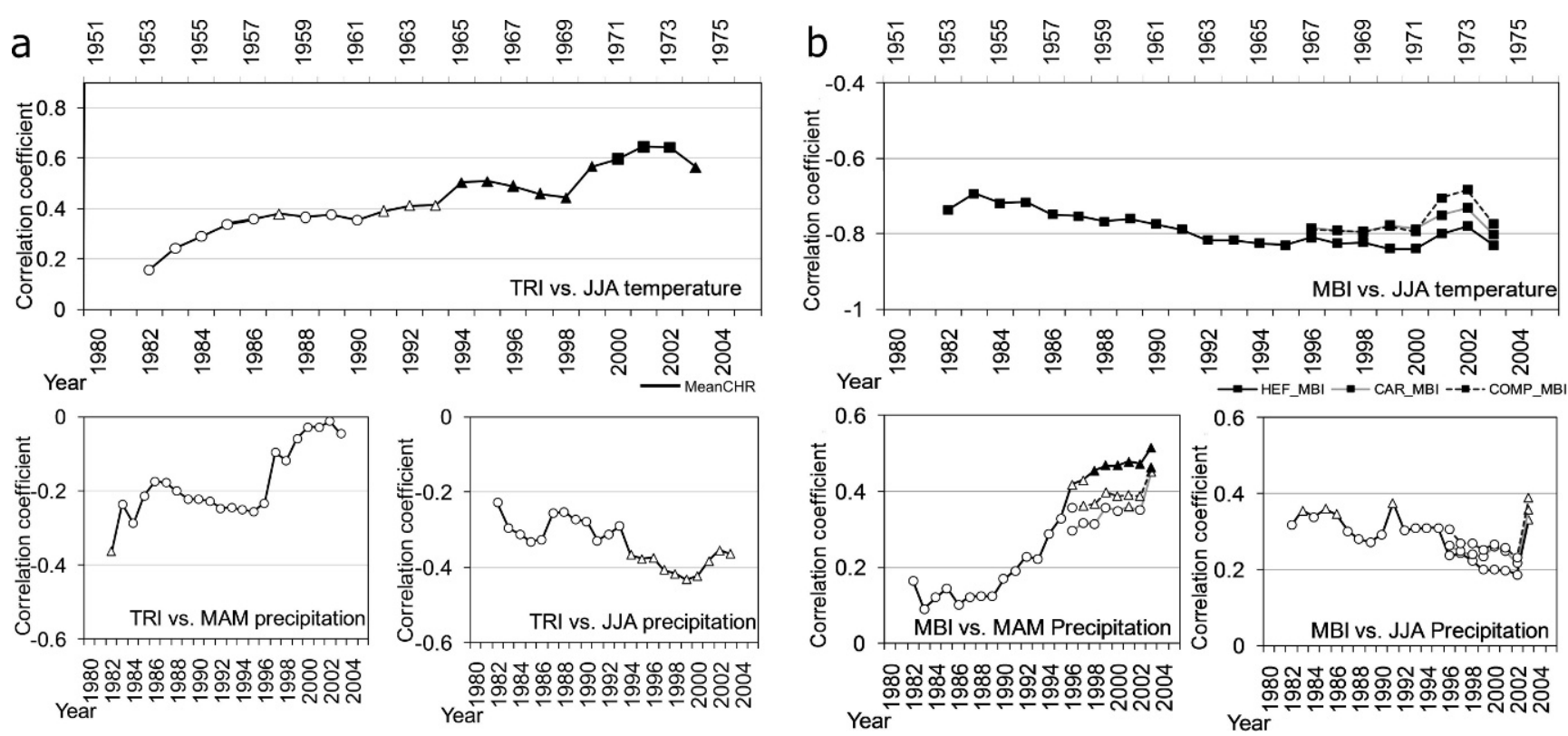

FIGURE 4. Bootstrapped correlation coefficients calculated for 30-year periods from 1953 to 1982 (1967 to 1993 for CAR and COMP series) and shifted by one year up to 1974-2003, between the mean chronology and JJA temperature, MAM and JJA precipitation anomalies (a), and between the three mass-balance series and the same climatic variables (b). In all graphs: $\square, p<0.001 ; \Delta, p<0.01 ; \triangle, p<0.05 ; \bigcirc$, not significant.

glacier area with altitude). The tongues of large valley glaciers may be especially sensitive to temperature change since a large portion of their bodies typically extend to low altitudes, where summer temperatures generally result in less snowfall and more melting. This could explain the higher sensitivity of glaciers, especially for the Hintereis Glacier, to spring (MAM) snowfall in recent decades (Fig. 4b)

The general convergence noticed between the three MBI series and the three tree-ring chronologies (Schr-HEF, -CAR, and -COMP; Fig. 5) is probably due to the increasing sensitivity of tree rings and glaciers to summer temperatures (Figs. 4a and 4b). The variation in the strength of the linear relationships over time between the MBI series of both large and small glaciers, and the tree-ring chronologies poses some limitations on the glacier massbalance reconstructions. The reconstruction of past mass balances of the small glaciers selected for this study appears to be especially problematic since the series are short and correlations are generally weaker and also more variable over time. Nonstationary relationships with climatic elements and between variations in climatic proxies (both physical and biological ones) have significant implications for all proxy-based reconstructions.

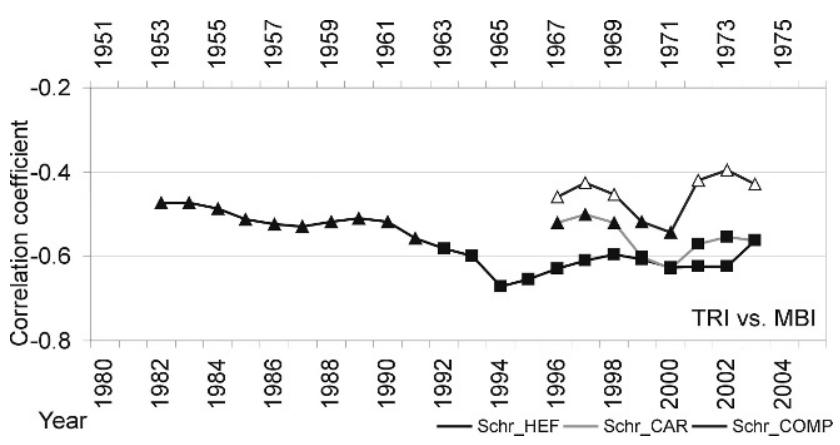

FIGURE 5. Bootstrapped correlation coefficients calculated for 30-year periods from 1953 to 1982 between the three Schr chronologies and the three MBI series. Symbols as in Figure 4.
Comparisons between the two climatic proxies, mass-balance series and tree-ring chronologies, have led to successful massbalance reconstructions in Europe and North America (Nicolussi and Patzelt, 1996; Lewis and Smith, 2004; Larocque and Smith, 2005; Watson and Luckman, 2004). Upon close examination of our dendrochronological data for the central European Alps, however, we found stronger correlations for the larger Hintereis Glacier series, whereas relationships to smaller glaciers closer to the dendroclimatic network were generally weaker. The tree-ring chronologies that correlated better with the MBI series (Schr) are those containing a stronger July and JJA temperature signal and a negative influence of March snow (Figs. 3a and 3b). Those chronologies presenting weaker correlations with the MBI (Wchr) also had weaker July and JJA temperature signals.

The regression of the MBI series on tree-ring chronologies always showed negative slopes, but the tree-ring chronologies always presented higher percentage of mass-balance variations of the Hintereis glacier than of the small glaciers. After removing the year 2003, considerably higher proportions of mass-balance variations were explained by tree-ring chronologies. These findings emphasize how the same climatic conditions drive nonproportional variations in glaciers' mass variations and tree-ring growth, especially in the years when extreme meteorological conditions induce strong variations. The different responses to climate could be related to the fact that these two climatic proxies respond to common but also different climate variables and to the fact that high-altitude trees have threshold temperatures above which they may not respond linearly (D'Arrigo et al., 2004). In particular, we found that tree rings mainly responded to July temperature and glacier mass balance to JJA temperature (Figs. 3a and 3c). Also the influence of precipitation variables slightly differs, with tree rings being mainly influenced by JJA precipitation and glaciers by January to May precipitation (Figs. 3b and 3d). Since precipitation is a controlling factor modulating both tree-ring growth and glacier mass balance, another possible improvement for mass-balance reconstruction in this area therefore could be the inclusion of precipitation-sensitive 

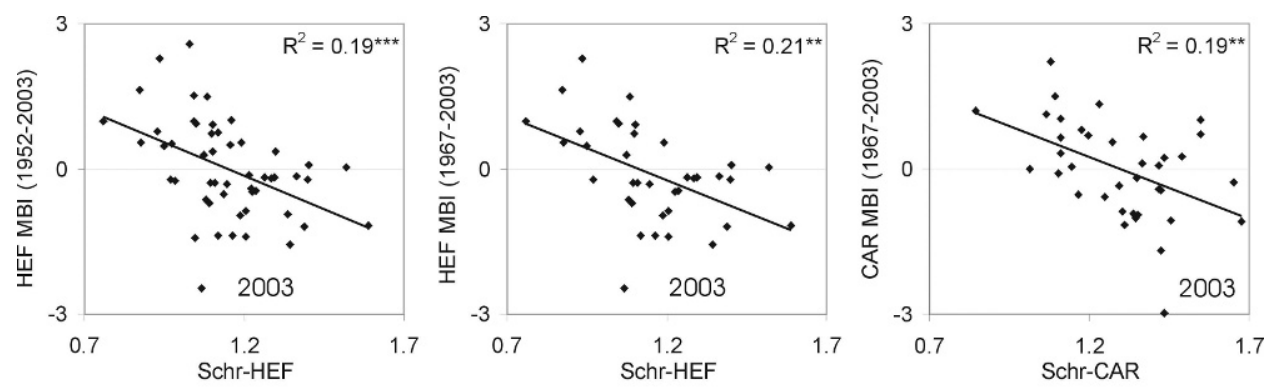

FIGURE 6. Regression of the Hintereis and Careser standardized MBI series on the Schr
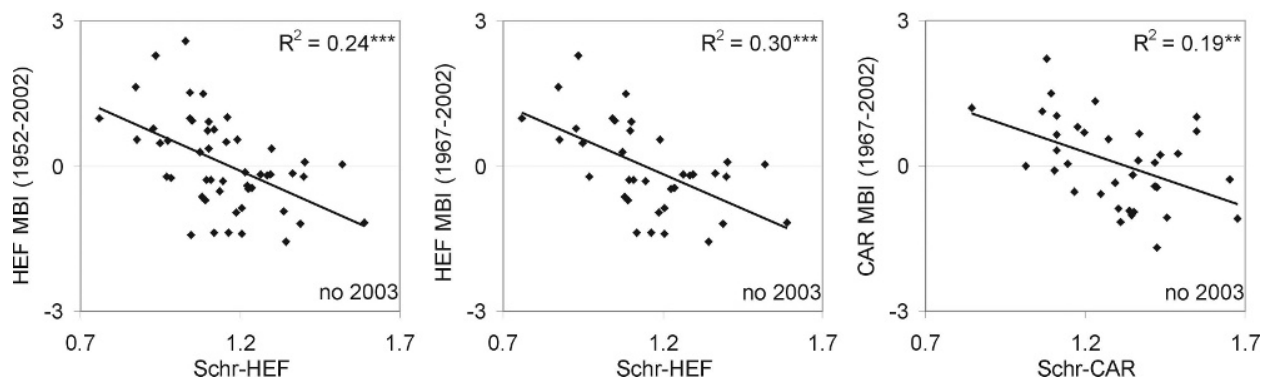
chronologies. The graphs below depict the regression after eliminating the year 2003. All the regressions were performed on the maximum period available, and, for the Hintereis series, also on the common period 1967-2003. The coefficient of determination and the significance level of each regression are also given $(* * *, p$ $<0.001$; **, $p<0.01)$.

chronologies and the consideration of winter and summer mass balances (Watson and Luckman, 2004).

\section{Conclusions}

Both glacier mass balance and tree rings from high-altitude sites show a non-stationary sensitivity to climate over time. The recent convergence between the glacier MBI series and ring-width chronologies was probably driven by the generally increasing sensitivity of the glacier mass balance to JJA temperatures and of the tree rings especially to $\mathbf{J}$ temperatures for the selected chronologies. This convergence between the two proxies may be mostly ascribed to the modern temperature regime over the region that shows a marked increasing trend both for JJA and $\mathrm{J}$ temperature. In the first portion of the considered period of analysis the two proxies were, instead, less correlated: changes in the climatic inputs occurred over different months and the generally cooler climatic regime may have caused different responses in the two proxies over time. This fact may pose some limitations on tree-ring-based glacier mass-balance reconstructions in the region studied, which may also apply in other mountain regions. The mass balance of the large Hintereis valley glacier generally correlated better with summer (JJA) temperatures than did those of small glaciers. These results indicate that treering-based glacier mass-balance reconstructions in the European Alps are probably more reliable for large than for small glaciers.

We found that summers with extremely warm conditions, which are likely to become more frequent in the European Alps (Beniston, 2007), are inducing strong mass variation in glaciers but they are not correspondingly enhancing ring widths. While tree rings may provide a fairly reliable mass-balance reconstruction of large glaciers, such a reconstruction cannot reveal years of strong ablation that could have occurred in the past. For the Central Alps we suggest that first tree-ring data should be used to reconstruct the mass balance of large valley glaciers. Non-stationary relationships with climatic elements over time also pose some problems for tree-ring based reconstructions, because typically only short calibration periods are available. Given our results, before applying the uniformitarian principle to reconstruct past glacier mass-balance changes, we recommend rigorous testing of both the physical and the biological climatic proxies over common

and maximum periods to determine what climatic variable they mostly respond to and to find out how stationary the influence of climate is over time.

\section{Acknowledgments}

This research was funded by the MIUR-COFIN 2005 and PRIN 2009 projects. The authors thank the reviewers for their useful comments and help, Dr. Reinhard Böhm (ZAMG, Vienna, Austria) for the HISTALP database, Dr. Silvia Dingwall for revising the English, Josée Frenette (Université du Québec AT) for fieldwork assistance, and the Stelvio National Park for treesampling permits.

\section{References Cited}

Auer, I., and 31 others., 2007: HISTALP-Historical instrumental climatological surface time series of the Greater Alpine Region. International Journal of Climatology, 27: 17-46.

Barnett, T. P., Adam, J. C., and Lettenmaier, D. P., 2005: Potential impacts of a warming climate on water availability in snow-dominated regions. Nature, 438: 303-309.

Beniston, M., 2003: Climatic change in mountain regions: a review of possible impacts. Climatic Change, 59: 5-31.

Beniston, M., 2007: Entering into the "greenhouse century": recent record temperatures in Switzerland are comparable to the upper temperature quantiles in a greenhouse climate, Geophysical Research Letters, 34: article L16710, doi:10.1029/2007 GL030144.

Bitz, C. M., and Battisti, D. S., 1999: Interannual to decadal variability in climate and the glacier mass balance in Washington, Western Canada, and Alaska. Journal of Climate, 12: 3181-3196.

Briffa, K. R., Bartholin, T. S., Eckstein, D., Jones, P. D., Karlén, W., Schweingruber, F. H., and Zetterberg, P., 1990: A 1,400-year tree-ring record of summer temperatures in Fennoscandia. Nature, 346: 434-439.

Büntgen, U., Frank, D. C., Schmidhalter, M., Neuwirth, B., Seifert, M., and Esper, J., 2006a: Growth/climate response shift in a long subalpine spruce chronology. Trees, 20: 99-110.

Büntgen, U., Frank, D. C., Nievergelt, D., and Esper, J., 2006b: Summer temperature variations in the European Alps, A.D. 755-2004. Journal of Climate, 19: 5606-5623. 
Carrer, M., and Urbinati, C., 2006: Long-term change in the sensitivity of tree-ring growth to climate forcing in Larix decidua. New Phytologist, 170: 861-872.

Carrer, M., Nola, P., Eduard, J. L., Motta, R., and Urbinati, C., 2007: Regional variability of climate-growth relationships in Pinus cembra high elevation forests in the Alps. Journal of Ecology, 95: 1072-1083.

Carturan, L., and Seppi, R., 2007: Recent mass balance results and morphological evolution of Careser Glacier (Central Alps). Geografia Fisica e Dinamica Quaternaria, 30(1): 33-42.

Cogley, J. G., and Adams, W. P., 1998: Mass balance of glaciers other than the ice sheets. Journal of Glaciology, 44: 315-325.

D’Arrigo, R. D., Kaufmann, R. K., Davi, N., Jacoby, G. C., Laskowski, C., Myneni, R. B., and Cherubini, P., 2004: Thresholds for warming-induced growth decline at elevational tree line in the Yukon Territory, Canada. Global Biogeochemical Cycles, 18: article GB3021, doi:10.1029/2004GB002249.

D’Arrigo, R., Wilson, R., Liepert, B., and Cherubini, P., 2008: On the 'divergence problem' in northern forests: a review of the tree-ring evidence and possible causes. Global Planetary Change, 60: 289-305.

Diolaiuti, G., Smiraglia, C., Reynaud, L., D’Agata, C., and Pavan, M., 2002: Relation entre les bilans de masse de la Sforzellina et ceux des autres glaciers en Europe. Influence des facteurs localisation géographique et taille du glacier. La Houille Blanche, 6/7: 59-63.

Dyurgerov, M., 2002: Glacier mass balance and regime. Data of measurements and analysis. Institute of Arctic and Alpine Research, University of Colorado, Occasional Paper 55, 268 pp.

Dyurgerov, M., 2006: Northern hemisphere glaciers responding to climate warming by increasing their sensitivity and their contribution to sea level rise. In Knight, P. (ed.), Glacier Science and Environmental Change. Oxford: Blackwell Publishing Ltd., 133-134.

Esper, J., Cook, E. R., and Schweingruber, F. H., 2002: Lowfrequency signals in long tree-ring chronologies for reconstructing past temperature variability. Science, 295: 2250-2253.

Esper, J., Cook, E. R., Krusic, P. J., Peters, K., and Schweingruber, F. H., 2003: Tests of the RCS method for preserving low-frequency variability in long tree-ring chronologies. Tree-Ring Research, 59: 81-98.

Fritts, H. C., 1976: Tree Rings and Climate. New York: Academic Press, $567 \mathrm{pp}$.

Haeberli, W., 1990: Glacier and permafrost signals of 20th-century warming. Annals of Glaciology, 14: 99-101.

Haeberli, W., and Hoelzle, M., 1995: Application of inventory data for estimating characteristics of and regional climatechange effects on mountain glaciers: a pilot study with the European Alps. Annals of Glaciology, 21: 206-212.

Haeberli, W., Hoelzle, M., Paul, F., and Zemp, M., 2007: Integrated monitoring of mountain glaciers as key indicators of global climate change: the European Alps. Annals of Glaciology, 46: 150-160.

Hoelzle, M., Haeberli, W., Dischl, M., and Peschke, W., 2003: Secular mass balances derived from cumulative glacier length changes. Global and Planetary Change, 36: 295-306.

Huber, U. M., Bugmann, H. K. M., and Reaonser, M., 2005: Global Change and Mountain Regions. An Overview of Current Knowledge. Advances in Global Change Research, Vol. 23. Dordrecht: Springer, $650 \mathrm{pp}$.

Hughes, L., 2000: Biological consequences of global warming: is the signal already apparent? Trends in Ecology and Evolution, 15: $56-61$.

Hughes, M. K., 2002: Dendrochronology in climatology-The state of the art. Dendrochronologia, 20: 95-116.

Intergovernmental Panel on Climate Change, 2007: Climate change 2007. In Parry, M. L., Canziani, O. F., Palutikof, J. P., van der Linden, P. J., and Hanson, C. E. (eds.), Impacts, Adaptation and Vulnerability. Contribution of Working Group II to the Fourth Assessment Report of the IPCC. Cambridge and New York: Cambridge University Press, 976 pp.

Jones, P. D., New, M., Parker, D. E., Martin, S., and Rigor, I. G., 1999: Surface air temperature and its changes over the past 150 years. Review of Geophysics, 37: 173-199.

Larocque, S. J., and Smith, D. J., 2005: Little Ice Age proxy glacier mass balance records reconstructed from tree rings in the Mt. Waddington area, British Columbia Coast Mountains, Canada. Holocene, 15: 748-757.

Leonelli, G., Pelfini, M., and Cherubini, P., 2008: Exploring the potential of tree-ring chronologies from the Trafoi Valley (Central Italian Alps) to reconstruct glacier mass balance. Boreas, 37: 169-178.

Leonelli, G., Pelfini, M., Battipaglia, G., and Cherubini, P., 2009: Site-aspect influence on climate sensitivity over time of a highaltitude Pinus cembra tree-ring network, Climatic Change. doi:10.1007/s10584-009-9574-6.

Letréguilly, A., and Reynaud, L., 1990: Space and time distribution of glacier mass balance in the northern hemisphere. Arctic and Alpine Research, 22: 43-50.

Lewis, D., and Smith, D., 2004: Dendrochronological mass balance reconstruction, Stachona Provincial Park, Vancouver Island, British Columbia, Canada. Arctic, Antarctic, and Alpine Research, 36: 598-606.

McCabe, G. J., Fountain, A. G., and Dyurgerov, M., 2000: Variability in winter mass balance of northern hemisphere glaciers and relations with atmospheric circulation. Arctic, Antarctic, and Alpine Research, 32(1): 64-72.

Meier, M. F., Dyurgerov, M. B., and McCabe, G. J., 2003: The health of glaciers: recent changes in glacier regime. Climatic Change, 59: 123-135.

Mihalcea, C., Mayer, C., Diolaiuti, G., Lambrecht, A., Smiraglia, C., and Tartari, G., 2006: Ice ablation and meteorological conditions on the debris covered area of Baltoro Glacier Karakoram. Annals of Glaciology, 43(1): 292-300.

Mokhov, I. I., Roeckner, E., Semenov, V. A., and and. Khon, V. C., 2006: Possible regional changes in precipitation regimes in northern Eurasia in the 21st century. Water Resources, 33(6): 702-710.

Nakawo, M., and Young, G. J., 1982: Estimate of glacier ablation under debris layer from surface temperature and meteorological variables. Journal of Glaciology, 28: 29-34.

National Snow and Ice Data Center, 2007, World Glacier Inventory. World Glacier Monitoring Service and National Snow and Ice Data Center/World Data Center for Glaciology. Boulder, Colorado, digital media (http://nsidc.org/).

Nemec, J., Huybrechts, P., Rybak, O., and Oerlemans, J., 2009 Reconstruction of the annual balance of Vadret da Morteratsch, Switzerland, since 1865. Annals of Glaciology, 50: 126-134.

Nicolussi, K., 1994: Jahrringe und Massenbilanz. Zeitschrift für Gletscherkunde und Glazialgeologie, 30: 11-52.

Nicolussi, K., and Patzelt, G., 1996: Reconstructing glacier history in Tyrol by means of tree-ring investigations. Zeitschrift für Gletscherkunde und Glazialgeologie, 32: 207-215.

Oerlemans, J., 2001: Glaciers and Climate Change. Rotterdam: A.A. Balkema Publishers, 148 pp.

Oerlemans, J., 2005: Extracting a climate signal from 169 glacier records. Science, 308: 675-677.

Oerlemans, J., Giessen, R. H., and van den Broeke, M. R., 2009: Retreating alpine glaciers: increased melt rates due to accumulation of dust (Vadret da Morteratsch, Switzerland). Journal of Glaciology, 55(192): 729-736.

Parmesan, C., 1996: Climate change and species range. Nature, 382: 765-766.

Paul, F., Kääb, A., Maisch, M., Kellenberger, T., and Haeberli, W., 2004: Rapid disintegration of Alpine glaciers observed with satellite data. Geophysical Research Letters, 31: article L21402, doi:10.1029/2004GL020816.

Paul, F., Machguth, H., and Kääb, A., 2005: On the impact of glacier albedo under conditions of extreme glacier melt: the 
summer of 2003 in the Alps. EARSeL Workshop on Remote Sensing of Land Ice and Snow, Berne, 21-23/2/2005. EARSeL Proceedings, 4(2): 139-149.

Pelfini, M., and Smiraglia, C., 1997: Signals of 20th-century warming from the glaciers in the Central Italian Alps. Annals of Glaciology, 24: 350-354.

Snedecor, G. W., and Cochran, W. G., 1989: Statistical Methods. 8th edition. Ames, Iowa: Iowa State University Press.

Solomina, O., Haeberli, W., Kull, C., and Wiles, G., 2008: Historical and Holocene glacier-climate variations: general concepts and overview. Global and Planetary Change, 60: 1-9.
Theurillat, J.-P., and Guisan, A., 2001: Potential impact of climate change on vegetation in the European Alps: a review. Climatic Change, 50: 77-109.

Watson, E., and Luckman, B. H., 2004: Tree-ring-based massbalance estimates for the past 300 years at Peyto Glacier, Alberta, Canada, Quaternary Research, 62: 9-18.

MS accepted September 2010 